УДК 636.47.085.8:633.34.

(C) 2015

Чухліб С. В., кандидат сільськогосподарських наук,

Голуб Н. Д., кандидат сільськогосподарських наук,

Скареднов Д. Ю., аспірант

(науковий керівник - доктор сільськогосподарських наук, професор А. А. Полішук)

Полтавська державна аграрна академія

\title{
ОСТЕОЛОГІЧНІ ДОСЛІДЖЕННЯ СВИНЕЙ ПОЛТАВСЬКОЇ М'ЯСНОЇ ПОРОДИ ЗА УМОВ ВИКОРИСТАННЯ СОСВИХ КОРМІВ РІЗНИХ ТЕХНОЛОГІЙ ПРИГОТУВАННЯ
}

\section{Рецензент - кандидат сільськогосподарських наук Т. П. Булавкіна}

Наведені результати відгодівлі свиней полтавської м'ясної породи з використанням соєвих кормів, виготовлених за різними технологіями (експандування під тиском, віджим під пресом, екструзія) та вплив даних білкових кормів на хімічний склад і міцність стегнових кісток. Більш продуктивними виявилися підсвинки, яких годували соєвим кониентратом (група Д1), соєвою макухою (група Д2) та соєвим екструдатом (група Д3). На відгодівлі вони показали середньодобові прирости 825-833-785 г відповідно, $i$ витратили на 1 кг приросту 3,26-3,47 кормових одиниць. У їх стегнових кістках було більше кальцію на 1,66-1,04-2,78\% і фосфору на 0,67-0,53-0,38\%, ніж у кістках тварин контрольної групи. Підсвинки дослідних груп мали дещо менший діаметр кістки на 0,51-0,33-0,73 мм, але більшу товщину кісткової стінки (крім групи Д2) на 0,35-0,24 мм. Найбільше навантаження на весь діаметр кістки зафіксовано у дослідній групі Д3.

Ключові слова: хімічний склад кісток, маса кістки, товщина кісткової стінки, навантаження на весь діаметр кістки, вік досягнення живої маси у 100 ке, середньодобовий приріст, витрати корму на 1 кг приросту, морфологічний склад туш.

Постановка проблеми. Ефективність відгодівлі свиней як на комплексах, так і в товарних господарствах різних форм власності у певній мірі залежить від міцності конституції тварин, з якою пов'язана їх продуктивність, здатність до відгодівлі, вік досягнення живої маси у 100 кг, схильність до різних захворювань та інші господарськобіологічні особливості тварин.

Свині з міцною конституцією повинні мати, насамперед, міцний кістяк, оскільки він виконує опорну функцію та $є$ резервом мінеральних речовин у тілі тварини $[1,2,5]$.

Міцність кістяка це своєрідний показник функціонального стану організму, на який у певній мірі впливає низький рівень годівлі свиней.
Встановлено, що недостатня годівля тварин у ранньому віці призводить до негативних наслідків їх розвитку на все життя $[8,10]$.

Аналіз основних досліджень і публікацій, у яких започатковано розв'язання проблеми. Ведення свинарства на високому рівні становить підвищені вимоги до міцності конституції свиней, 3 якою тісно пов'язані господарськобіологічні особливості $[6,9]$. Дослідження цілої низки вчених свідчать про те, що на міцність кістяка мають вплив такі фактори, як порода, вік, умови утримання та умови годівлі свиней $[6,7]$. Аналіз літературних джерел показав, що міцність кісток $є$ своєрідним критерієм оцінки конституційної міцності і функціонального стану організму $[8,6]$. Існують й інші дані щодо міцності кістяка свиней - так у дослідах [4] зазначається, що на міцність кісткової тканини у більшій мірі впливає статева належність тварин, аніж порода. Виходячи 3 вищезазначеного, виникає необхідність подальшого дослідження даного питання.

Об'єктом досліджень були свині полтавської м'ясної породи державного підприємства «Експериментальна база «Надія» Інституту свинарства та АПВ НААН України».

Метою досліджень було встановити та проаналізувати вплив білкових соєвих кормів, виготовлених за різними технологіями (експандування під тиском, віджим під пресом, екструзія), на відгодівельні, забійні якості та хімічний склад, розвиток і міцність стегнових кісток свиней полтавської м'ясної породи.

Завданням наших досліджень було встановлення впливу білкових соєвих кормів різних технологій приготування на відгодівельні, забійні якості свиней полтавської м'ясної породи та на міцність їх стегнових кісток.

Методика досліджень. Науково-дослідна робота виконувалась в умовах державного підпри- 


\section{СІЛЬСЬКЕ ГОСПОДАРСТВО. ТВАРИННИЦТВО}

ємства «Експериментальна база «Надія» Інституту свинарства та АПВ НААН України» на поголів'ї свиней полтавської м'ясної породи в зимовий період 2013 року. Експериментальна робота проведена 3 метою вивчення впливу білкових кормів на хімічний склад та міцність стегнових кісток свиней за методикою А. А. Фрідчера [9]. Для досліджень відбиралися праві стегнові кістки, які після висушування у термостаті при температурі $+37{ }^{\circ} \mathrm{C}$ до постійної маси, були піддані випробовуванню на міцніть за статичного згину на універсальній машині УММ-20.

Водночас визначали:

- масу кісток, в грамах;

- довжину, в сантиметрах;

- товщину кісткової стінки, в міліметрах;

- навантаження на весь діаметр, в кілограмах.

Дослідження проведені за схемою досліду з використанням білкових соєвих кормів: група Д1 - КСБСК; Д2 - макуха соєва; Д3 - екструдат соєвий; за контроль взята макуха соняшникова - група К (табл. 1).

Результати досліджень. Відгодівельні та забійні якості піддослідних тварин є основними i найбільш цінними властивостями, від яких певною мірою залежить показник ефективності ви- робництва свинини. Отримані результати, наведені в таблиці 2, свідчать, що кращими за відгодівельними якостями є свині групи Д2. Так, живої маси 100 кг вони досягли за 225 діб, що на 12 діб швидше, ніж тварини 3 контрольної групи, та на 3 і 7 - від свиней з групи Д1 і Д3, відповідно. Показники середньодобового приросту та витрати кормів на 1 кг приросту також були кращими у свиней із групи Д2. Вони становили 833 г, що вище, ніж у ровесників контрольної групи на 16,0\%, груп Д1, Д3 на 1 та 6 \% відповідно.

Витрати корму становили 3,26 кормових одиниць, що на рівні із групою Д1, але менше, ніж у свиней із контрольної групи на $12 \%$ та 3 групи Д3 на 6,4 \%. Морфологічний склад туш, досліджений шляхом обвалки правих напівтуш, дає більш повне уявлення про м’ясність піддослідних тварин. Встановлено, що свині групи Д2 мали найбільшу кількість м'яса - 56,29 \%, що більше, ніж у ровесників контрольної та груп Д1 і Д3 на 2,32-0,36-1,16 \% відповідно. За кількістю сала перевагу мали свині контрольної групи $35,40 \%$, найменшу - тварини 3 групи Д2 $32,83 \%$. У ровесників групи Д1 та Д3 цей показник становив 33,97-33,85 \%.

\section{1. Схема науково-господарського досліду}

\begin{tabular}{|c|c|c|c|c|}
\hline \multirow{2}{*}{$\begin{array}{c}\text { Дослідні групи } \\
\text { тварин }\end{array}$} & \multirow{2}{*}{$\begin{array}{l}\text { Кількість } \\
\text { голів }\end{array}$} & \multicolumn{2}{|c|}{ Періоди досліду } & \multirow[b]{2}{*}{ Система утримання } \\
\hline & & $\begin{array}{c}\text { Підготовчий } \\
\text { (15 днів) }\end{array}$ & $\begin{array}{c}\text { Обліковий } \\
\text { (76 днів) }\end{array}$ & \\
\hline К - контрольна & 12 & $\begin{array}{c}\text { ОР з макухою } \\
\text { соняшнику }\end{array}$ & $\begin{array}{l}\mathrm{OP}-82+\text { макуха } \\
\text { соняшнику } 18 \%\end{array}$ & $\begin{array}{c}\text { Станкове } \\
\text { по } 2 \text { голови }\end{array}$ \\
\hline Д1 - дослідна & 12 & $-/ /-$ & $\begin{array}{c}\mathrm{OP}-82+\text { концентрат } \\
\text { соєвий } 18 \%\end{array}$ & $-/ /-$ \\
\hline Д2 - дослідна & 12 & $-/ /-$ & $\begin{array}{c}\text { ОР }-82+\text { макуха соєва } \\
18 \% \\
\end{array}$ & $-/ /-$ \\
\hline Д3 - дослідна & 12 & $-/ /-$ & $\begin{array}{c}\mathrm{OP}-82+\text { екструдат } \\
\text { соєвий } 18 \%\end{array}$ & $-/ /-$ \\
\hline
\end{tabular}

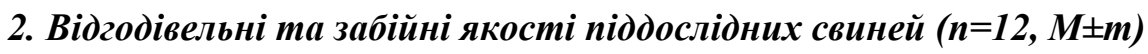

\begin{tabular}{|c|c|c|c|c|c|c|}
\hline \multirow[b]{2}{*}{ હ } & \multicolumn{3}{|c|}{ Відгодівельні якості } & \multicolumn{3}{|c|}{ Морфологічний склад туш, \% } \\
\hline & $\begin{array}{c}\text { Вік досягнен- } \\
\text { ня живої маси } \\
100 \text { кг, днів }\end{array}$ & $\begin{array}{c}\text { Середньодо- } \\
\text { бовий приріст, } \\
\text { грам }\end{array}$ & $\begin{array}{c}\text { Витрати } \\
\text { корму на } \\
1 \text { кг при- } \\
\text { росту, к.од. }\end{array}$ & М'ясо & Сало & Кістки \\
\hline $\mathrm{K}$ & $237 \pm 3,24$ & $720 \pm 20,83$ & $3,65 \pm 0,10$ & $53,97 \pm 2,70$ & $35,40 \pm 2,53$ & $10,63 \pm 0,38$ \\
\hline Д1 & $228 \pm 2,22$ & $825 \pm 21,94$ & $3,26 \pm 0,11$ & $55,93 \pm 0,54$ & $33,97 \pm 0,45$ & $10,10 \pm 0,50$ \\
\hline Д2 & $225 \pm 2,56$ & $833 \pm 14,83$ & $3,26 \pm 0,07$ & $56,29 \pm 2,39$ & $32,83 \pm 3,11$ & $10,88 \pm 0,72$ \\
\hline Д3 & $232 \pm 3,32$ & $785 \pm 28,56$ & $3,47 \pm 0,10$ & $55,13 \pm 1,15$ & $33,85 \pm 2,10$ & $11,02 \pm 1,05$ \\
\hline
\end{tabular}


СІЛЬСЬКЕ ГОСПОДАРСТВО. ТВАРИННИЦТВО

\section{3. Остеологічна характеристика стегнових кісток $(n=3, M \pm m)$}

\begin{tabular}{|c|c|c|c|c|c|c|c|c|c|c|}
\hline \multirow{3}{*}{ 胥 } & \multicolumn{10}{|c|}{ Показники } \\
\hline & \multicolumn{2}{|c|}{ Маса кістки, г } & \multicolumn{2}{|c|}{$\begin{array}{c}\text { Довжина } \\
\text { кістки, см }\end{array}$} & \multicolumn{2}{|c|}{$\begin{array}{c}\text { Середній діаметр } \\
\text { кістки, мм }\end{array}$} & \multicolumn{2}{|c|}{$\begin{array}{c}\text { Середня довжина } \\
\text { кісткової стінки, } \\
\text { мм }\end{array}$} & \multicolumn{2}{|c|}{$\begin{array}{c}\text { Навантаження на } \\
\text { весь діаметр, кг }\end{array}$} \\
\hline & $\mathrm{M} \pm \mathrm{m}$ & $\mathrm{Cv}, \%$ & $\mathrm{M} \pm \mathrm{m}$ & C, \% & $\mathrm{M} \pm \mathrm{m}$ & $\mathrm{Cv}, \%$ & $\mathrm{M} \pm \mathrm{m}$ & $\mathrm{Cv}, \%$ & $\mathrm{M} \pm \mathrm{m}$ & $\mathrm{Cv}, \%$ \\
\hline K & $190,54 \pm 5,66$ & 5,14 & $\begin{array}{c}19,93 \pm \\
0,07 \\
\end{array}$ & 0,58 & $22,53 \pm 0,29$ & 2,22 & $\begin{array}{c}4,63 \pm \\
0,02 \\
\end{array}$ & 0,82 & $355,00 \pm 47,26$ & 23,06 \\
\hline Д1 & $173,84 \pm 16,67$ & 16,61 & $\begin{array}{c}19,30 \pm \\
0,29 \\
\end{array}$ & 2,59 & $22,02 \pm 1,33$ & 10,45 & $\begin{array}{c}4,98 \pm \\
0,30 \\
\end{array}$ & 10,57 & $353,33 \pm 73,56$ & 36,06 \\
\hline Д2 & $175,01 \pm 17,56$ & 17,38 & $\begin{array}{c}19,27 \pm \\
0,43\end{array}$ & 3,90 & $22,20 \pm 1,15$ & 9,00 & $\begin{array}{c}4,37 \pm \\
0,33\end{array}$ & 13,26 & $351,67 \pm 76,72$ & 37,79 \\
\hline Д3 & $171,67 \pm 14,20$ & 14,33 & $\begin{array}{c}19,27 \pm \\
0,81\end{array}$ & 7,27 & $21,80 \pm 0,53$ & 4,19 & $\begin{array}{c}4,87 \pm \\
0,18\end{array}$ & 6,50 & $360,00 \pm 66,58$ & 32,03 \\
\hline
\end{tabular}

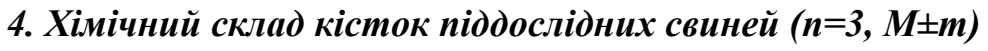

\begin{tabular}{|c|c|c|c|c|c|c|c|}
\hline \multirow{2}{*}{ 胥 } & \multicolumn{5}{|c|}{ Хімічний склад, \% } & \multirow{2}{*}{ Р:Сa } \\
\cline { 2 - 7 } & \multicolumn{2}{|c|}{ Зола } & \multicolumn{2}{|c|}{ Кальцій } & \multicolumn{2}{c|}{ Фосфор } & \\
\cline { 2 - 7 } & $\mathrm{M} \pm \mathrm{m}$ & $\mathrm{Cv}, \%$ & $\mathrm{M} \pm \mathrm{m}$ & $\mathrm{Cv}, \%$ & $\mathrm{M} \pm \mathrm{m}$ & $\mathrm{Cv}, \%$ & \\
\hline К & $37,17 \pm 1,38$ & 6,4 & $13,42 \pm 0,21$ & 2,6 & $3,58 \pm 0,20$ & 9,6 & 0,27 \\
\hline Д1 & $40,03 \pm 2,59$ & 11,2 & $15,08 \pm 2,52$ & 28,9 & $4,25 \pm 0,02$ & 0,6 & 0,28 \\
\hline Д2 & $39,02 \pm 1,73$ & 7,7 & $14,46 \pm 0,66$ & 7,9 & $4,11 \pm 0,36$ & 15,1 & 0,28 \\
\hline Д3 & $43,24 \pm 1,87$ & 7,3 & $16,20 \pm 0,43$ & 4,6 & $3,96 \pm 0,37$ & 16,1 & 0,24 \\
\hline
\end{tabular}

Аналіз остеологічних показників (табл. 3) свідчить, що найбільшу масу мали стегнові кістки свиней контрольної групи - 190,54 г, що на 109-11\% вище, ніж маса кісток тварин груп Д1, Д2, Д3.

За показниками довжини кісток та їх середнім діаметром суттєвої різниці не виявлено, проте дещо вищими вони були у контрольній групі (19,93 см та 22,53 мм) відповідно. Найбільша товщина кісткової стінки була у кісток свиней групи Д1 - 4,98 мм, що на 7,6-14-2,3 \% більше, ніж у кісток тварин контрольної групи та групи Д2 і Д3.

Найвищий показник навантаження на весь діаметр кістки зафіксований у групі Д3 - 360 кг, це на 5,0-6,7-8,3 кг, або 1,4-2-2,4 \% більше, ніж у контрольній та дослідних групах Д1 і Д2.

Хімічний аналіз стегнових кісток піддослідних тварин (табл. 4) показав, що вміст золи та кальцію був більшим також у кістках свиней групи Д3 відносно контрольної та груп Д1, Д2 на $6,07-3,21-4,22 \%$ та на $2,78-1,12-1,74 \%$.

Найбільше фосфору зафіксовано у кістках тварин групи Д1 - 4,25\%, найменша його кількість у контрольній групі - 3,58\%. Співвідношення
P:Са у кістках свиней груп Д1; Д2 становило 0,28, у контрольній - 0,27, а в групі Д3 було на рівні 0,24 .

Таким чином, проведені досліди дають можливість зробити наступні висновки:

1. Відгодівля свиней полтавської м'ясної породи 3 використанням соєвих кормів позитивно вплинула на відгодівельні та забійні якості піддослідних тварин, а також на міцність їх кістяка.

2. Результат обвалки туш піддослідних свиней свідчить, що за найвищого середньодобового приросту у 833 грам, найбільший вихід м'яса i найменший сала мали тварини із групи Д2 56,29 та 32,83 \% відповідно (годівля соєвою макухою).

3. Остеологічні дослідження довели, що вищий вміст кальцію $(16,20 \%)$ та найбільше навантаження на весь діаметр кісток $(360,0$ кг) був у свиней із дослідної групи ДЗ (годівля соєвим екструдатом).

Отже, отримані результати дослідів дають можливість стверджувати, що за відгодівлі свиней доцільно використовувати соєву макуху та екструдат. 


\section{БІБЛІОГРАФІЯ}

1. Гетя $A$. Продуктивные качества свиней с различной крепостью конечностей / А. Гетя // Свиноводство. - 1997. - №4. - С. 11-13.

2. Гниденко C. С. Влияние условий выращивания хряков на крепость костяка / С. С. Гниденко // Животноводство. - 1985. - №8. - С. 28-29.

3. Жисулін С. П. Вплив умов утримання на розвиток стегнових кісток свиней / С. П. Жигулін // Свинарство. - 1994. - №50. - С. 77-79

4. Иссык В. В. Развитие прочности скелета новой породы свиней / В. В. Иссык // Труды института экспериментальной биологии. - 1980. T. 14. - C. 154-161.

5. Криштофорова Б. В., Лемещенко В. В., Стегней Ж. Г. Біологічні основи ветеринарної неонатології / Б. В. Криштофорова, В.В.Лемещенко, Ж. Г. Стегней. - Сімферополь : Терра таврика, 2007. - 366 c.

6. Лісний В., Пелих В. Розвиток і міцність кісток чистопородних та гібридних підсвинків / В. Лісний, В. Пелих // Тваринництво України. -
1997. - №5. - C. 15.

7. Остапчук П. П., Доманський А. Я. Показники росту деяких трубчатих кісток у свиней різних порід в зв'язку з віком і типом годівлі / П. П. Остапчук, А. Я. Доманський // Свинарство. 1973. - №19. - С. 80-84.

8. Тертишник Л. Л. Міцність стегнових кісток свиней ландрас і великої білої породи в залежності від умов вирощування / Л. Л. Тертишник // Вісник сільськогосподарських наук. - 1987. №12. - C. 55-57.

9. Фридчер А. А. Прочность бедренных костей у свиней в зависимости от возраста и происхождения / А. А. Фридчер // Труды Новосибирского СХИ. - 1980. - Т. 133. - С. 23-26.

10. Чирвинский П. К вопросу о развитии костяка свиней при нормальных условиях, при недостаточном питании и после кастрации самцов в раннем возрасте / П. Чирвинский // Сочинение. 1949. - T. 1. - C. 377-521. 